\title{
Europolis - from a Piratical Republic to a Collective Colony
}

There was almost no dry land here. The reeds and marsh came right up to the river, and then little by little, according to the work to be done, a solid band was formed along the river by ballast discharged from ships, so the soil there is made up of samples from every quarter of the globe. Nothing could be more cosmopolitan.

HUBERT LYAUTEY, 1931

A graduate of the Naval College in Galați, Eugeniu P. Botez (1874-1933) served as 'maritime commissioner' of Sulina. He was charged, on behalf of the Romanian state, between 1909 and 1913, with the attributions which were not carried out by the Captain of the Sulina Harbour appointed by the European Commission of the Danube. Botez was later promoted to the rank of commander in the Romanian navy. In the interwar years, he was one of the country's leading experts in seamanship, but also enjoyed national fame as a writer: he authored several literary volumes under the pseudonym 'Jean Bart', a seventeenth-century French naval commander and privateer. Botez was a pioneer in Romanian literature through his interest in seafarers and maritime stories. His masterpiece is a novel called Europolis, an account of life in Sulina in the early twentieth century as Botez witnessed during his employment there.

To Botez, the place was 'a small global citadel, a cosmopolitan port-city, which, though almost unique worldwide, is extremely original and very little known'. The prospect of easy profits had attracted adventurers of all sorts who came to Sulina 'to fish in the troubled waters of the Danube'. Sulina/Europolis

1 A biography in Constantin Mohanu, Jean Bart (Eugeniu Botez). Viața și opera (Bucharest 2001). 
was a 'mosaic of all races, nations and languages', an exotic port at the junction of East and West, North and South, rendered even stranger by the international organisation - 'a Europe in miniature' - that regulated the rhythms of its existence. $^{2}$

Botez published his novel in 1933, at the peak of the Great Depression, when Sulina was far from its previous prosperity. Things had changed tremendously in the past century, as the Danube Delta got caught in an inter-imperial political and military vortex. Sulina was annexed by Russia in 1829 , destroyed by the British navy in 1854, occupied by the Austrians in 1855 , given to the Moldavians in 1856 , returned to the Ottomans in 1857 , bombarded by the Russians in 1877 , taken over by the Romanians in 1878 , caught in the crossfire during the First World War and defended by the Russians in 1916. Local authorities changed as often. One of the few things that remained unaltered was Sulina's position as a relay station at the confluence of river and sea. It was this strategic position and the Commission's technical improvements that turned it into the operational headquarters of an experimental international organisation.

By the interwar period the river had been 'civilised' by state-of-the-art hydraulic works, brigands had been 'disciplined' by modern regulations, and the town provided modern services to its inhabitants. But 'civilisation' also brought an end to Sulina's heroic times, when cunning entrepreneurs could earn many a fortune from trade and shipping. Mercantile imagination and private initiative were replaced by routine and social benefits generously paid for by the Commission. The hundreds of petty businessmen who had made Sulina's prosperity in the mid- and late nineteenth century were long gone, replaced by as many employees of the Commission. The IO's staff amounted, in 1930, to 359 people, plus 746 temporary workers, most of them based at Sulina. ${ }^{3}$ The town was a 'safe' place for navigation and for its inhabitants, but social insecurity during a period of sharp economic decline and uncertainty for the long-term development of the place made its prospects look bad. It seemed that the rule of law and institutionalised trade had destroyed prosperity and replaced it with some sort of 'vulnerable stability'.

In the late 1930s the Commission lost most of its attributions, coveted by revisionist Romania, eager to claim back its wounded national sovereignty. In 1948 , under the direction of the Soviet Union, the last remnants of an 'imperialist organisation' were dismantled. A new, 'democratic' Danube Commission, based in Budapest from 1954, took over the role of securing navigation on the river (see Chapter 10). With the coming of communism, most non-Romanian

2 Jean Bart, Europolis (Bucharest s.a.).

3 La Commission Européenne du Danube et son œuvre de 1856 à 1931 (Paris 1931), 109. 

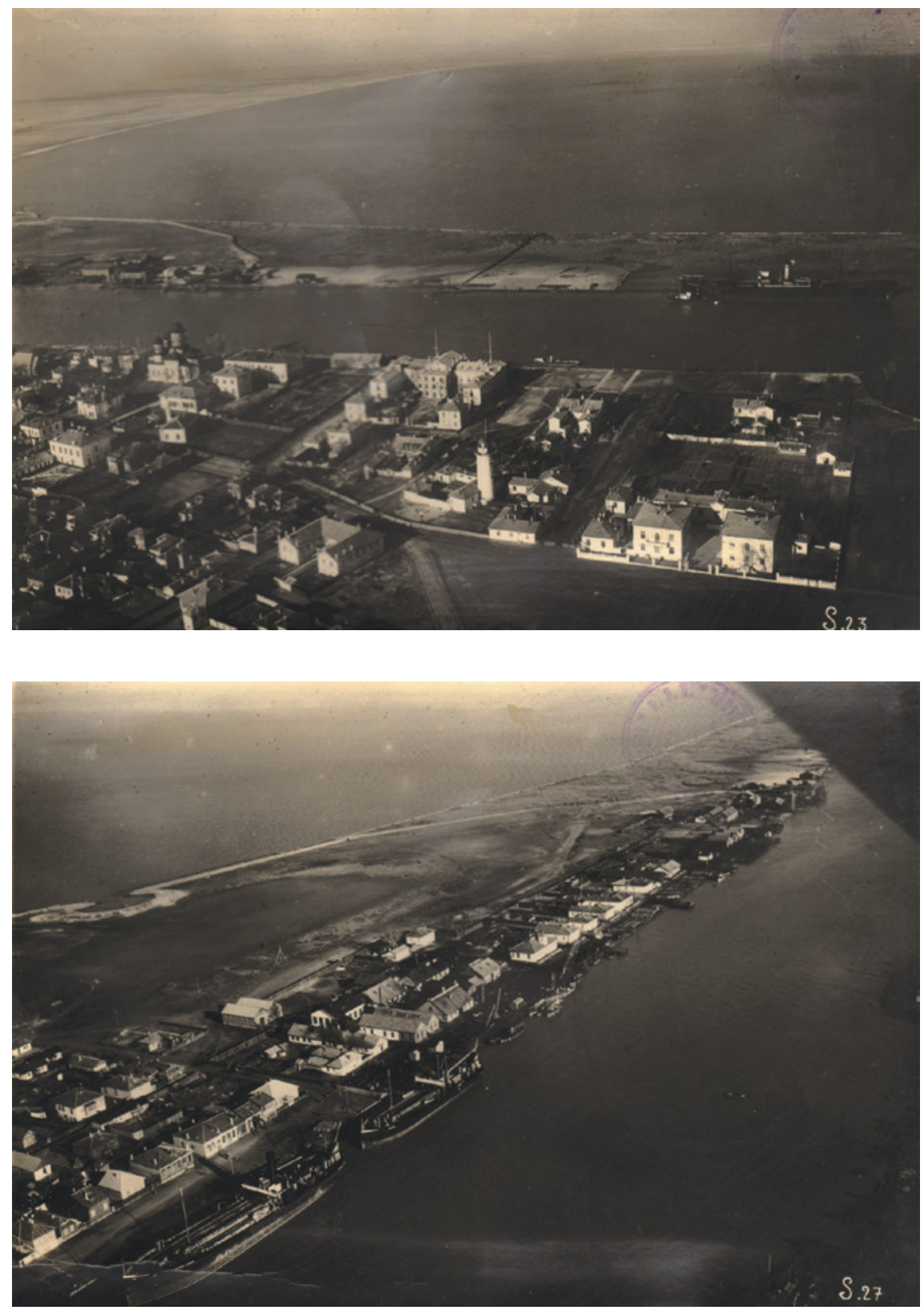

FIGURES 17-18 Sulina - aerial views (1930)

SOURCE: THE NATIONAL ARCHIVES OF ROMANIA, GALAȚI BRANCH 
inhabitants left, and a new workforce was attracted from the Danube Delta to populate several small factories established in Sulina, serving as proof of the Romanian authorities' determination to industrialise the furthest corners of the country. Industry collapsed with the post-communist privatisation of the 1990s, and the town now tries to survive by rebranding itself as a touristic venue with a fabulous and cosmopolitan past.

The marked socio-economic decline of a formerly prosperous settlement which preserves a vivid memory of its past glory has attracted a lot of academic interest from scholars in the humanities and social sciences. Sulina and the Danube Delta do not lack fashionable and thought-provoking approaches fuelled by their unique mix of geographical and historical peculiarities. Cultural anthropologists describe Sulina as a hybrid of margin and centre, and consider it an illustrative example of an area where fluid or liquid boundaries (conceptual, social and spatial) intertwine and interconnect. The town was marginal from a geographical-territorial perspective, placed as it was in a marshland at the end of empires. At the same time, Sulina was central to several fluvial and maritime transportation networks that rendered it easily reachable from the Danubian outlets of Brăila and Galați, and from the major commercial centres of the Black Sea and Europe. Placed at a crossroads of steamboat lines, Sulina had direct economic relations with Istanbul and Odessa, Vienna and Piraeus, Trieste and Marseille, London and Rotterdam. At a certain time in its existence, it acquired some central functions, and attracted experts, capital and know-how because of the Commission, which invested not only in the hydraulic improvement of the Danube, but also in developing the political, commercial and cultural relevance of its host town. Sulina's singular position was constructed in relation 'to the interplay of centre, periphery and boundary', an equation in which its liminal position between East and West acted as 'a divider and connector for its cosmopolitan inhabitants'.

Despite such rich scholarly interest, Sulina's history remains little-known and this chapter aims to reveal several episodes in its fascinating history as - to

4 See for example Kristof van Assche, Petruța Teampău, Patrick Devlieger and Cristian Suciu, 'Liquid Boundaries in Marginal Marshes. Reconstructions of Identity in the Romanian Danube Delta,' Studia Universitatis Babeș-Bolyai, Sociologia 53.1 (2008): 115-133; van Assche, Devlieger, Teampău and Gert Verschraegen, 'Forgetting and Remembering in the Margins: Constructing Past and Future in the Romanian Danube Delta,' Memory Studies 22 (2009): 211-234; van Assche and Teampău, 'Layered Encounters: Performing Multiculturalism and the Urban Palimpsest at the "Gateway of Europe,"' Anthropology of East Europe Review 27.1 (2009): 7-19; van Assche, Martijn Duineveld, Raoul Beunen and Teampău, 'Delineating Locals: Transformations of Knowledge/Power and the Governance of the Danube Delta,' Journal of Environmental Policy \& Planning 13.1 (2011): 1-21, etc. 
borrow from Valeska Huber's description of Suez - an 'imperial relay station'. Since its creation in 1856 , the Commission was the main source of stability and prosperity for Sulina, and three dimensions relevant for making a security regime for navigation will be presented below: the political/administrative component, with the establishment of law and order through close cooperation between the organisation and local authorities; economic aspects, with the Commission's contribution to the commercial progress of Sulina, which resulted in its transformation into a privileged, tax-free international enclosure and the busiest port on the Danube; and the social dimension, with a cosmopolitan population which grew through international colonisation ${ }^{6}$ and had to face the many threats of Sulina's exposed position as a global contact zone of various forms of mobility. ${ }^{7}$ By mapping how the Commission dealt with very dynamic and illusive threats and opportunities, this chapter will illuminate the special relationship that an early IO had with its host town - the perfect example of an 'international locality' envisioned by Scottish law professor James Lorimer in the 1870 s (Chapter 3 ).

\section{Imperial Security-Making and a 'Piratical Republic under Austrian Protection'}

Establishing law and order in Sulina, a faraway border town in the wild, wild East, was never a simple task. A combination of factors accounted for that, from its eccentric geographical position and rough climate to its demographic structure and administrative leadership. Consular sources kept referring to the anarchy that ruled in Sulina in Russian times (Chapter 1) under the lax control of allegedly corrupt officials. This vivid image of sheer banditry was presented in many of the Commission's subsequent publications. It was a benchmark to showcase the organisation's contribution to the 'civilisation' of what came to be the Danube's busiest port. In the following pages, narrative sources will be used to portray this image of anarchical destitution and how the Commission gradually started to have a say in bringing law and order to the mouths of the Danube.

5 Valeska Huber, Channelling Mobilities: Migration and Globalisation in the Suez Canal Region and Beyond, 1869-1914 (Cambridge and New York 2013), 35.

6 Huber, 'Connecting Colonial Seas: The "International Colonisation” of Port Said and the Suez Canal During and After the First World War,' European Review of History/Revue européenne d'histoire 19.1 (2012): 141-161.

7 Huber, Channelling Mobilities, 1. 
Sulina had been the scene of heavy fighting during the summer of 1854, when, in the context of the Crimean War, the British navy attacked the town in an attempt to annihilate its batteries. Captain Hyde Parker of HMs Firebrand fell while leading his marines, but his comrades eventually took the town. According to a report by Commander Richard A. Powell of HMs Vesuvius, the Russian military quarter in Sulina, an enclosure of 'about 50 Government houses, stables, storehouses, and a magazine', was 'entirely demolished, the houses destroyed, and nothing now marks the spot but a heap of ruins'. Most of the town, except for its main street, was set on fire. ${ }^{8}$

Danubian trade quickly revived in the spring of 1855 , nourished by the huge demand for agricultural produce at a time when Russian grain exports were blocked by the war. With it, Sulina returned to its anarchical state. The first entrepreneurs to go back were the same allegedly dishonest pilots and colluding lightermen who created and exploited navigational obstacles to their profit. Johann Baptist Coronini-Cronberg, the Austrian general who commanded the imperial forces in occupation of the Principalities of Moldavia and Wallachia, decided to intervene and restore order at the mouths of the Danube. In July 1855, two warships, the Ceres and the Gyula, were sent to Sulina under the command of Major Baumrucker, who acted as military commander of the town. About 50 commercial ships, which were blocked upstream of the bar, hailed the Austrian arrival, and Baumrucker started to draft and impose rules. A municipal administration was established with representatives of all local nationalities, the revenue of the commune was fixed, and its income covered by levying moderate taxes. The piloting service was regulated, the lighthouse repaired, several wrecks were removed from the fairway, and the navigable channel was buoyed. Some sort of law and order started to be enforced, and money collected from the booming trade was to be used for the establishment of a hospital, served by military physicians. Engineers surveyed the area with the view to choosing the most appropriate river branch and mouth for improvement. ${ }^{9}$ Habsburg efficiency seemed to have 'tamed' the terrible Danubian 'pirate den'.

In early 1856, Lieutenant Wilhelm von Tegetthoff (1827-1871), in command of the Taurus, took over the Sulina station. Tegetthoff, a promising naval officer and, later in his career, Chef der Marinesektion of the Habsburg Empire,

8 'Admiralty, July 27, 1854, London Gazette, no. 21576, Friday 28 July 1854: 2321-2322; details on the context and the several military operations at Sulina in Tudose Tatu, Sulina. Asalturi însângerate 26.06 - 08.07- 17.07. 1854 (Galați 2009).

9 Alfons von Wimpffen, Erinnerungen aus der Wallachei während der Besetzung durch die österreichischen Truppen in den Jahren 1854-1857 (Vienna 1878), 211. 
vividly depicted life at Sulina in private letters sent to his father in Vienna. Only the lighthouse and Greek church had survived from Russian Sulina, a 'nest of thieves and a rallying place for rogues', a town rising from the surrounding swamp along a narrow strip of land as the Danube flowed into the Black Sea. It somehow resembled Venice in a very primitive phase of its evolution, and was worthy of its nickname - the 'New California'. In this dreary place lighterage was extremely remunerative for crowds of transnational brigands, who continued their unlawful practices and robbed commercial vessels of their cargoes. There were no fancy houses in Sulina, only 'small thatched huts', each accommodating dozens of people. Houses and people seemed poor enough, but enormous fortunes were spent in equally wretched pubs and prices of daily goods soared. These were good reasons, Tegetthoff thought, for the comparison with California. A census recorded 234 houses and 1,755 inhabitants, almost all of them men. ${ }^{10}$

The lieutenant further mentioned the Austrian attempts to clear the Sulina bar, an initiative that had brought to the Maritime Danube several engineers, capitalists and officers. Major Joseph Mitesser von Dervent was one of them. Dervent was appointed in charge of the Sulina hydraulic works and Lieutenant Tegetthoff applauded his rival's fiascos in trying to clear the bar. Beyond the official reports of Austrian agents, these private letters show that removing the natural and artificial obstacles that impeded Danubian navigation was not as simple as the Viennese officials had believed. It was vital for them to start gathering knowledge on local geography, hydrography and commercial practices before being able to come up with a long-term solution."

A similar opinion is suggested by other sources that refer to the state of 'perfect anarchy' that prevailed in 1856 at Sulina, where the inhabitants had returned and 'lived in complete lawlessness' in a sort of 'piratical republic under Austrian protection. ${ }^{12}$ Rather than believing that the Austrians managed to rapidly discipline such an eclectic party of unruly entrepreneurs, it is more probable that they insisted on resuming mercantile operations at a time when the grain market was booming.

\footnotetext{
10 Adolf Beer, Aus Wilhelm von Tegetthoff's Nachlass (Vienna 1882), 108-137.

11 Ibid. See more recently, for the Austrian occupation of the Danube Delta, Luminița Gătejel, 'Building a Better Passage to the Sea: Engineering and River Management at the Mouth of the Danube, 1829-61', Technology and Culture 59.4 (2018): 933-935.

12 Dr Michelson, 'Trade in Connection with the Navigation of the Danube,' The Nautical Magazine and Naval Chronicle for 1858. A Journal of Papers on Subjects Connected with Maritime Affairs (London 1858), 242.
} 
Sulina remained under Austrian rule throughout 1856, and its occupation was hailed by many contemporaries who considered it the best solution for 'civilising' the place and its inhabitants. The Crimean War victors, however, as discussed in previous chapters, granted the Danube Delta to Moldavia, under the sovereignty of the Sublime Porte, ${ }^{13}$ and in 1857 transferred it into the safer hands of the Ottoman Empire. ${ }^{14}$ By February 1857, the Austrian troops withdrew from Sulina, and the Ottoman authorities took over the local administration throughout the Danube Delta. At the same time, the Commission, which convened at Galați in November 1856, was interested in establishing law and order in the port of Sulina, the most vital settlement for the progress of Danubian trade and shipping.

In 1857, Sulina became part of the Ottoman sanjak of the Danube Delta. Troops, administrators and ships were assigned for the security of local inhabitants, but it took a long time to impose anything resembling law and order over a marshland with an imprecise geography and a bad transportation infrastructure. Provincial authorities were based in the town of Tulcea, outside of the Delta proper, about 70 kilometres from Sulina, a town reachable to this day by water only.

There were innumerable problems to be solved to remedy the state of sheer uncertainty which reigned in Sulina. One of them concerned the status of properties. With the transfer of territory from Russia to the Ottoman Empire, this needed to be clarified. When Russia had annexed the Danube Delta in 1829, the Treaty of Adrianople incorporated Sulina into a demilitarised strip of land along the Russian-Ottoman borderline. As described in Chapter 1, only buildings serving quarantine purposes could be erected, and Sulina flourished around the quarantine station established there in the mid-1830s. But following the merchants' requests for clearer land property regulations in the $1840 \mathrm{~s}$ and $1850 \mathrm{~s}$, local Russian authorities seemed more disposed to disregard the allegedly provisional character of the town.

As land was scarce, it was extremely valuable. New administrative decisions concerning estates were taken in Austrian times in $1855^{-1856}$, so the status of properties was even more unclear when the Ottomans settled in at Sulina

13 Congrès de Paris 1856 (Paris 1856), 13.

14 Hertslet's Commercial Treaties: A Collection of Treaties and Conventions, Between Great Britain and Foreign Powers, vol. 10 (London 1859), 553-554. 
in early 1857. Ottoman commissioner Ömer Fevzi Pasha, who also served as governor of the Danube Delta, reported to his government about the foreign merchants' requests to buy land. The only way to reject such petitions was 'to make these estates the private property of the Sultan' and allow them to be rented, but not sold. ${ }^{15}$ However, according to the 1856 Paris Peace Treaty, the inhabitants of the territory lost by Russia had a respite period of three years in which they were 'permitted to transfer their domicile elsewhere, disposing freely of their property.16 Clarifying property rights was an important part in the execution of the treaty, and it allowed consuls to interfere in the process on behalf of their subjects. Soon, local inhabitants started to complain about being deprived of the land they had formerly occupied or of not being allowed 'to rebuild their burnt houses or to acquire ground and build elsewhere'. With complete urban chaos and very little land available on the marshy island where Sulina lies, the Ottoman authorities promised, by August 1857, to bring civil engineers to plan out the town, while an administrative board was to be appointed to investigate disputed property titles. ${ }^{17}$

By then there were about 3,000 inhabitants in the town, many of them Ionians with British protection. Thousands of seafarers, whose ships were often blocked at Sulina, added to a much larger floating population. Approximately 150 Ottoman troops were stationed in the port to keep order in Sulina, but they had difficulty controlling a hostile Christian population that had lived well in Russian and Austrian times. Violence was common and when, in May 1857, two Ottoman marines murdered a local Ionian, tensions were on the verge of exploding. ${ }^{18}$ When Rashid Bey, newly appointed kaymakam of Sulina, arrived at his residence in August 1857, he struggled to cope with the anarchy of a town in the making.

A contemporary narrative is perhaps best placed to portray living conditions in a settlement that was emerging from the oozing marshes of the Danube Delta. To German physician Wilhelm Haam, who arrived in Sulina in 1857, the place was much like Dante's inferno: a 'city of agony and condemnation' where voyagers should better 'abandon all hope'. Haam emphasised the material fragility of the entire town, where 'houses', or rather tents, were built

\footnotetext{
15 Türkiye Cumhuriyeti Cumhurbaşkanlığı Devlet Arşivleri Başkanlığı (Republic of Turkey Presidential State Archives, formerly known as Başbakanlık Osmanlı Arşivi - hereafter BOA), HR.SYS 1604/55 (5 February 1857) and I..DH 413/27364 (25 S 1275) (4 October 1858).

16 Congrès de Paris, 13 (Article 21).

17 The National Archives of the United Kingdom (TNA), Public Record Office, Foreign Office, Fund 195 (The Ottoman Empire), File 523, f. 583 (St Vincent Lloyd to Viscount Stratford de Redcliffe, Sulina, 20 August 1857).

18 Ibid., f. 542-546 (the same, 27 May 1857).
} 
from textiles, reeds or parts of shipwrecked vessels. The main street consisted of two long rows of such provisional huts, filled with the most diverse people one could imagine. But what stunned the visitor was the 'unfathomable turmoil, the screaming, singing, laughing, whistling, calling, melody' he encountered. Every building was at the same time 'a shop, a tavern and a playroom'. 'Craftsmen, peaceful citizens, families do not exist here', in a place where 'the dregs of entire Europe came together: runaway sailors, hunted pirates, escaped galley convicts, murderers, who hide from the law or from the blood revenge, gamblers who are too well-known everywhere else, deserters, crooks of every kind and category'. All found safe refuge under the lax local Ottoman authorities, as they had done in Russian times in a town which needed labour and where people could earn fortunes in lighterage operations. ${ }^{19}$

In a report sent to the Foreign Office, Joseph Hutton Dupuis (1827-1903), Britain's vice-consul in Sulina from $1860-1872$, provided more details on the nature of property claims in Ottoman Sulina. The Ottomans had become masters of the town, but most estates belonged to Christian subjects. Dupuis accused the local authorities of pursuing a systematic policy of spoliation, oppression and violence against the Christian inhabitants. They elected, nevertheless, four of the eight members of the local Medjlis, the 'Legislative Council' presided over by the $k a d \iota$, but their political power was however extremely limited. ${ }^{20}$

Returning to 1857 , with a town in the making on the empire's northern border, Ottoman authorities were no guarantee for the security of Danubian navigation..$^{21}$ In such circumstances, commissioners from Galați felt they had to get involved in pacifying Sulina. ${ }^{22}$ They started to draft regulations for navigation, piloting and lighterage etc. and looked to impose them by using their formal and informal authority. The ambiguous legal situation of an Ottoman territory under an international jurisdiction proved helpful for turning Sulina into an administrative experiment. Even more helpful was a military force readily available for European delegates to enforce their authority.

19 Wilhelm Haam, Südostliche Steppen und Städte, nach einiger Anschauung geschildert (Frankfurt am Main 1862), 61-87.

20 Captain S.G.B. St Clair and Charles A. Brophy, A Residence in Bulgaria: Or, Notes on the Resources and Administration of Turkey (London 1869), 271-274. An Ottoman view on the construction of two Muslim and one Christian neighbourhoods at BOA, I.DH 413/27362 (25 S 1275) (4 October 1858).

21 воА, нR.мкт.мнм 120/24 (30 Ra 1274) (18 November 1857) and HR.SYS 1607/42 (31 December 1859).

22 TNA, FO 195/523, f. 519 (Lloyd to Stratford de Redcliffe, Sulina, 19 March 1857). 


\section{On the Beginnings of Peacekeeping Corps - European Warships at} Sulina

Since Russia became riparian to the Black Sea in the eighteenth century, the issue of local naval bases and the passage of warships through the Turkish Straits had been the object of numerous international agreements. If the Russian-Ottoman Treaty of Hünkâr İskelessi (1833) opened the Bosporus and the Dardanelles to Russian warships in case of a general European war, the London Convention of 1841 cancelled this agreement and barred all military passage through the Straits. After Russia's defeat in the Crimean War, the victors went one step further in their objective to limit Russian naval pressure on Istanbul, stipulating in Article 11 of the 1856 Paris Treaty that the Black Sea be neutralised. There were, however, two exceptions: one concerned 'the force and the number of light vessels' necessary for the 'services' (i.e. border, customs or sanitary control) of the two riparian empires; the other aimed to secure the execution of the regulations for Danubian navigation, so each power had 'the right to station, at all times, two light vessels at the Mouths of the Danube.' ${ }^{23}$

The latter exception was, most probably, included in the treaty given the Austrians' experience in coping with the anarchy of Sulina. The presence of their warships at the Maritime Danube had been deemed vital for the security of the entire area. From 1856 all seven signatory powers acquired this right, which was mainly used by the countries that had economic interests to defend in the Black Sea area. In 1858, for example, the Austrians kept two steamers at Sulina, the Taurus and the Croatia, France had the Auverne and the Meurtrière, Great Britain the Weser and the Boxer, and the Sardinians the Anthione. ${ }^{24}$ These light warships were not stationed permanently at Sulina, but plied between there and Galați for various missions or for ceremonial display during the Commission's plenary sessions, and rotated to their countries' naval bases in the Mediterranean.

The Commission discussed how to make good use of this force, and though there were many disagreements with the Ottoman Empire in its capacity as territorial power, the naval stations at Sulina were important not least in containing the subjects of each power. Moreover, in a town with few modern public services available, the crew on the Auverne proved decisive, in 1857, in extinguishing a fire that threatened to burn the entire locality. ${ }^{25}$ British sources claimed that the warships' authority extended all the way along the Maritime

23 Congrès de Paris, 9-12.

24 'The Danube,' Nautical Magazine 27 (1858): 328-329.

25 Ibid.: 328 . 
Danube, as 'the officers and crews of our gunboats are the puzzle and terror of the subaltern authorities of Galatz'.6 The light warships were equally useful for conducting scientific research in the Danube Delta or for allowing delegates increased mobility along the Danube and in the Black Sea. Later, the 1865 Public Act, known as the Commission's 'Constitution' (Chapter 3), stated that the execution of the organisation's regulations was ensured with the support of these warships:

Each naval station acts on the vessels of its nationality and on those whose flag it is called to protect, either by treaty or custom, or by general or special delegation. In the absence of a warship having a standing to intervene, the authorities in charge of the police of the river may resort to the warships of the territorial power. ${ }^{27}$

After 1871, when Russia remilitarised the Black Sea, foreign warships assumed an even more important symbolic value as agents of Europe in an area that witnessed a resurrection of Russian bellicosity.

Given the structure of Danubian trade and large number of British vessels calling at Sulina, British warships were especially important in preserving law and order at the Maritime Danube. HMs Cockatrice was one of the light warships dispatched to the Danube from its home base in Malta. While at the Lower Danube in 1866, H Ms Cockatrice had a crew of 40 seamen, who spent their spare time playing cricket, quoits or football. ${ }^{28} \mathrm{~A}$ decade later, however, in the context of a looming conflict between Russia and the Ottoman Empire, the presence of international warships was essential for regional security. According to a report, 'the maritime working population of Sulina, composed of Greeks, Turks, and Tartars, is comparatively very considerable in number, and consists of the very lowest classes'. The Ottomans strengthened their military hold, as 'some sixty or seventy soldiers have arrived' to support local policemen. As there had been serious disturbances between Christians and Muslims, westerners requested the presence of a gunboat to be permanently

26 'The Lower Danube,' in The Nautical Magazine and Naval Chronicle for 1859 (London 1859), 437 .

27 The London Gazette, No. 23105, 24 April 1866.

28 'Marinarii englezi jucau fotbal lângă Dunăre încă din 1865!', Evenimentul zilei, 8 September 2010 (online at http://evz.ro/marinarii-englezi-jucau-fotbal-langa-dunare -inca-din-1865-905259.html) (visited on 17 September 2017). 
stationed at Sulina, 'until such time as all apprehensions of disorder or danger shall be over. ${ }^{29}$

HMS Cockatrice was duly dispatched to Sulina and in October 1877, when the Russian navy attacked the Ottoman fleet, the British warship protected the Commission's assets by virtue of the IO's neutrality. ${ }^{30}$ In fact, the Russians prewarned the British commander of their imminent attack, and the Commission managed to convince the Ottoman military leadership to move their naval equipment which, by being a target for the enemy, threatened the organisation's property. In early 1878 , when Sulina was occupied by Russian troops, they were instructed not to breach the Commission's rights and privileges. ${ }^{31}$

The 1878 Berlin Peace Treaty maintained the right of these warships to be stationed at the mouths of the Danube, and with the transfer of Dobrudja and the Danube Delta to Romania, the Romanian navy dispatched several warships to Sulina to defend its national interests and new subjects. ${ }^{32}$ Romania mobilised larger human and material resources to secure its hold on one of the country's most strategic borders. By the 188 os, with its incorporation into the Romanian administrative system and more clearly regulated commercial practices, Sulina was a safer settlement. Warships continued to visit it, as presented in Chapter 3, but their protocolary function prevailed over their policing role.

The foreign warships and their crews may be considered some of the world's earliest peacekeeping forces. Similar to the military observers that the Security Council of the United Nations has been deploying since 1948, the role of the Danubian light warships was to allow the execution of an international agreement. They did so mainly by monitoring, reporting and confidence-building on the ground, all decisive steps for bringing stability to an anarchy-torn region. In the past few decades, the UN has shifted and developed its field operations from 'traditional' missions involving observational tasks performed by military personnel to more complex and multidimensional enterprises, designed to implement 'comprehensive peace agreements and assist in laying the foundations for sustainable peace'. Peacekeepers, now active in protecting civilians and supporting sustainable institutions of governance and restoring the rule of law, very often in 'remote, uncertain operating environments and

\footnotetext{
29 Correspondence Respecting the Affairs of Turkey, presented to both Houses of Parliament by Command of Her Majesty 1877 (London 1877), 449-450.

30 Ștefan Stanciu, România și Comisia Europeană a Dunării. Diplomație. Suveranitate. Cooperare internațională (Galați 2002), 98.

31 Nicolae Bîrdeanu and Dan Nicolaescu, Contribuții la istoria marinei române (Bucharest 1979).

32 Carmen Atanasiu, 'Dunărea în sistemul de apărare națională. Din istoricul garnizoanei de marină Sulina,' Anuarul Muzeului Marinei Române 14 (2011): 176-186.
} 
volatile political contexts', have a little-known precursor in the naval stations of the Maritime Danube. ${ }^{33}$

\section{5 From Shipping Security to the Making of a Free-Trade Zone}

A new town was gradually emerging at Sulina in the late 1850 , and the Commission contributed directly and decisively to its growth. One of the decisions that added to the town's economic prosperity related to the regulation and application of the customs regime within the Ottoman dominions.

Free-trade zones, known in the modern age as free ports or porto franco, are areas 'within which goods may be landed, handled, manufactured or reconfigured, and reexported without the intervention of the customs authorities. Only when the goods are moved to consumers within the country in which the zone is located do they become subject to the prevailing customs duties. ${ }^{34}$ Such free-trade zones are established nowadays around major transportation hubs (large seaports or international airports) or at state borders. In the Black Sea, the free port regime was introduced at Odessa in 1819, and it accounted for much of the Ukrainian outlet's commercial success. The inland Danubian ports of Brăila and Galați enjoyed a similar customs regime from $1835^{-1836}$, when they copied Odessa's status and witnessed an economic boom in the coming decades. Unsurprisingly, there were several requests in the 1830 s to turn Sulina into a porto franco, but they were unacceptable given the international status of the Danube Delta, along a demilitarised inter-imperial borderline.

By the end of the Crimean War, consular parties in the Principalities resumed their demands to establish a free port at the mouth of the Danube, chosen to be improved for permanent navigation. The Commission discussed such a privileged status for Sulina, and Édouard-Philippe Engelhardt, the French commissioner, studied it in detail. ${ }^{35}$ In a memorandum sent to his colleagues, he referred to some solutions that could reduce the threats that lighters and seagoing ships faced when loading grain in the Sulina roadstead. The

33 Details at https://peacekeeping.un.org/. See A.J. Bellamy, P.D. Williams and S. Griffin, Understanding Peacekeeping (Cambridge 2010) for an academic perspective on peacekeeping.

34 'Free Trade Zone,' online at https://www.britannica.com/topic/free-trade-zone (visited on 15 June 2018).

35 Centre des Archives diplomatiques de Nantes (CADN), Représentant de la France auprès de la Commission Européenne du Danube (CED), Série B, file 10 (Minutes des dépêches du commissaire de France avec le ministère des Affaires étrangères), f. 296v-302 (No. 147 and appendixes, Édouard-Philippe Engelhardt to the French Foreign Office, Galați, 19 November 1861). 
entrepreneurial community could have enjoyed better conditions in the local harbour, together with lower lighterage and insurance costs, more employment in wintertime, and increased shipping security. ${ }^{36}$ Engelhardt considered that such advantages could be secured if the Ottoman government would formally recognise Sulina as a free port, so that goods arriving in the privileged enclosure were stored there indefinitely and reshipped without being subject to any right of entry, exit or transit. As goods landed in the harbour were already exempt from customs duties for a limited amount of time, Engelhardt hoped for a positive response from the Ottoman authorities. ${ }^{37}$

The initiative included the proposal to allow foreigners the right to build storehouses at Sulina, which was hardly straightforward, given the unclear status of land ownership and the available land estates in the area. But the Ottoman government had an additional reason to reject the French request for a free port: Engelhardt envisaged the creation of a Mixed Court for cases relating to foreign nationals, ${ }^{38}$ a further violation of the territorial power's sovereign rights.

In 1869, Engelhardt's successor, Baron Adolphe d'Avril, asked his Ottoman colleague if foreign merchants could buy land and build storehouses and houses at Sulina, and if the goods unloaded in the harbour for re-exportation were exempt from customs dues. Commissioner Suleyman Pasha alluded to a new Ottoman law in use since $1867,{ }^{39}$ which allowed foreign subjects to acquire urban and rural land all over the empire, except for the holiest sites of Islam. Permission was granted on condition that they accepted equality with Ottoman citizens and were subject to Ottoman institutional and legal jurisdiction on all questions relating to property. While the law was passed under the pressure of European powers, it did, however, attempt to remove responsibility for land matters from the sphere of consular influence. ${ }^{40}$

In this new legal context, the customs regime became open for negotiation, and eventually in April 1870 Sulina was declared a free port. ${ }^{41}$ The decision implied the establishment of a privileged enclosure where customs exemptions

36 The National Archives of Romania, Galați Branch, Protocols of the European Commission of the Danube (hereafter PECD), Protocols 132 and 141, 29 June and 30 November 1861.

37 La Commission, 311-313.

38 PECD, Protocol 141, 30 November 1861.

39 Ibid., Protocol 238, 2 November 1869.

40 Ruth Kark, 'Consequences of the Ottoman Land Law: Agrarian and Privatization Processes in Palestine, 1858-1918,' in Chand Raghubir, Etienne Louis Nel and Stanko Pelc (eds.), Societies, Social Inequalities and Marginalization: Marginal Regions in the 21st Century (Cham 2017), 101-119. 
were applicable. As such delimitation was never done, the entire town was a de facto free trade zone.

When Romania acquired this territory in 1878 , several disputes followed concerning the porto franco regime. The Parliament in Bucharest had already discussed the repeal of all of Romania's free ports, which no longer fitted the protectionist views of the country's political leadership. Sulina's privileged status was not as burdensome for the national economy but incorporating the town into the national body was a symbolic victory for the newly independent Romanian state. The Commission, at the same time, insisted on the strict preservation of all its previous rights, including the free port regime for Sulina.

Faced with international pressure, the Romanian government agreed, by January 1879, to maintain the customs exemptions for Sulina. Notwithstanding this promise, octroi taxes were levied by the municipality on all articles landed, even on those destined for the use of the Commission and its employees (Chapter 8). Although Sulina was a free port in relation to ordinary, stateimposed customs taxes, the Romanians considered that municipal authorities had the right to levy octroi taxes on all goods landed in the town. Several commissioners insisted on the 'exceptional status' of the town, which deserved 'exceptional rules', inasmuch 'as that port is itself an exception, an artificial creation of the Danube Commission, an establishment exclusively devoted to the service of the navigation'. French commissioner Jules Herbette drafted a new motion, which maintained that the complete exemption from all customs dues was a special privilege of the entire town. ${ }^{42}$

Negotiations for a solution continued for the next couple of years. On the one hand the Commission was aware of the need to compromise but tried to bargain for as many of its benefits as possible. One of its main concerns had to do with its own financial situation. An excessive increase in the cost of living that affected its employees could unionise them and make them claim financial compensation. The grounds seemed reasonable enough: employees had been 'engaged at a time when the price of provisions in the town was far cheaper than at present' and they could now order goods from elsewhere which were admitted to Sulina duty free. ${ }^{43}$ Another reason concerned naval stores and coal, which had turned Sulina into a cheap revictualling station for

42 Ibid., Protocol 331, 26 May 1879 and TNA, FO 881/4301, f. 41 (Herbert Taylor Siborne to the Marquis of Salisbury, Galați, 27 June 1879).

43 TNA, FO 881/4301, f. 77 (the same, 9 October 1879). 
seagoing ships, so maritime powers had a direct interest in keeping naval provisions as inexpensive as possible. ${ }^{44}$

In several of its meetings, the Commission discussed the issue, and the Romanian delegate, Eustațiu Pencovici, made it clear that his government accepted full immunity for the goods necessary for the organisation and for its employees, but wanted clearer verification procedures to avoid abuses. ${ }^{45}$ Romanian authorities also agreed that octroi taxes be limited to a maximum of 5 per cent on articles necessary for revictualling shipping. ${ }^{46}$ Eventually, in 1883 the Romanian government abolished the porto franco regime for all its ports. Sulina, however, continued to enjoy its privileged status as proof of Romania's honest cooperation with Europe.

In an analysis of free ports around Europe in the early twentieth century, Sulina was an exceptional case among the only thirteen ports on the continent that still enjoyed such a privilege: nine in Germany (Hamburg, Bremerhaven, Cuxhaven, Geestemünde and the free districts of Bremen, Emden, Stettin, Brake and Danzig), two in Austria-Hungary (Trieste and Fiume), and one in Denmark (Copenhagen).

The circumstances and arrangements at Sulina are peculiar. The whole port, a length of three miles of the central mouth of the Danube, is free. Its principal business is the transhipment and export of cereals from higher up the river; and there is a Customs inspection to enforce the export tax thereon. The only taxation on goods discharged is an octroi duty on goods for local consumption. The freedom of the port does not extend to coal, which must be placed in bond. The port is isolated by marshes, and there is practically no general import trade and no passage of goods from the port into the interior. It is interesting to learn from the Consular report for 1908 that whatever industries Sulina possesses it owes to the fact that it is a free port. The privileges of Sulina are due to the international character of the Danube. Those of the German and Austrian ports are an historical survival. ${ }^{47}$

\footnotetext{
44 Ibid., FO 881/3861, f. 58-59 (the same, Thames Ditton, 13 January 1879) and FO 881/4301, f. 230-231 (the same, 28 February 1880).

45 PECD, Protocol 348, 15 September 1879; TNA, FO/4301, f. 195-196 (William White to Salisbury, Bucharest, 20 January 1880) and f. 230-231 (Siborne to Salisbury, Thames Ditton, 28 February 1880).

$46 \quad$ PECD, Protocols 386 and 391, 29 November and 4 December 1881.

47 'Hamburg and Other Free Ports,' The Economist, no. 3437, 10 July 1909: 59 and 'Free Ports; Liverpool and Hamburg,' ibid., no. 3459, 11 December 1909: 1199.
} 
This privileged status contributed to the prosperity of Sulina, a place where prices were much lower than in the rest of the country. To a Canadian visitor, everything was ' 30 per cent cheaper than up the river, as this is a free port'. 48 After the First World War, as smuggling duty-free goods to the mainland grew considerably, the Romanian government debated the best means of arresting it. In 1929, the Commission consented to the physical adjustment of the boundaries of the free port enclosure without affecting its legal regime. Eventually, the free port privilege was abolished in 1931. There were several attempts to restore it and, with it, the port's long-gone prosperity, but they all failed. ${ }^{49}$

The free port status did not increase the security of shipping operations in the local harbour, as Engelhardt had hoped in the early 186os. The main reason was land scarcity and the investors' reluctance to build warehouses for grain and other goods at a time (the 1870s) when the Commission's future was still uncertain. But the free port privilege strengthened the special bond between the Commission and its operational host town, whose wealth it secured by keeping prices of materials needed for its works, but also of everyday goods for its employees and the entire population, as low as possible.

Sulina is not usually included in the list of territories administered by international actors. The concept of internationalisation of territories dates back to the 1815 Vienna Congress, when Austria, Prussia and Russia decided to establish their shared authority over the Free City of Cracow. The experiment lasted until 1846, and a similar approach was used by the multinational administrations in Shanghai (1845-1944), Crete (1897-1909) and Tangier (1923-1957). The direct administration of territories by an IO emerged with the creation of the League of Nations, which was directly involved in the interwar years in the administration of the Saar Basin and the Free City of Danzig. In a post-war context, the practice of international territorial administration gained new traction in the realm of maintaining peace and security and has been successfully used in many areas around the globe. ${ }^{50}$

Sulina's case fits into a special category. The organisation was tasked to do hydraulic works and, while based in a far-off marshland, its agents realised that the proper administration of their host town was crucial for the success

48 Ethel Greening Pantazzi, Roumania in Light \& Shadow (Toronto 1921), 118. Other examples in I. Dragoslav, 'Sulina,' Albina. Revistă enciclopedică populară 17.32 (4 May 1914): 1260 and Constantin Bondar, Virginia Dima and Eugenia Iacovici Lungu, Sulina: monografie, vol. II (Bucharest 2010), 81.

49 Petru Zaharia, 'Sulina - porto franc (1870-1939),' Peuce 8 (1980): 520; Bondar et alii, Sulina, II, 90 .

$5^{0}$ Carsten Stahn, The Law and Practice of International Territorial Administration: Versailles to Iraq and Beyond (Cambridge 2008), 1-40. 
of their mission. Whereas the Commission's authority was restricted to preserving law and order along the navigable fairway of the Danube, it used the hazy legal status of the area, controlled by weak territorial states (the Ottoman Empire and, after 1878, Romania), to gradually spread its authority in the town of Sulina. When the Berlin Treaty granted the Commission 'complete independence of the territorial authority', its hold on Sulina further strengthened as it took and exercised direct control over some of the town's central institutions (the Harbour Master's Office, the lighthouse and the hospital), all part of an 'international enclosure'. But the free port regime was, in Ottoman and Romanian times, the ultimate proof of how profitable this special relationship between the Commission and Sulina was for all its inhabitants, including the representatives of the territorial power. A de facto condominium existed at Sulina between the Commission and the local Ottoman/Romanian authorities, well aware of the true source of the town's status and prosperity. But outside Sulina, in inland Danubian ports and in Romania's capital, this close cooperation was not regarded equally well, and the Commission's image gradually eroded amongst nationalist groups eager to fully restore the country's injured sovereign rights.

Steaming to Profit - Commercial Opportunities at the Lower Danube in the Post-Crimean War Context

Since the late 185 os, the impressive hydraulic works conducted along the Sulina branch and at its mouth aimed to increase the depth of the river with a view to allowing seagoing ships to sail between the Black Sea and the large Danubian ports of Brăila and Galați. With the success of the Commission's technical and normative activity the town was expected to return to its role as navigational gateway and victualling station. Lighterage, the emergency solution for shipping in insecure times, was, however, far from being ruined. Quite the opposite.

In the post-Crimean War context, the entire Black Sea area became an attractive market for western investors. The story of Stephanos Xenos, a Greek entrepreneur based in London, is illustrative of both the advantages and the problems of the Danubian market in the late 1850 and early 1860 . In 1856 Xenos operated a line of sailing vessels from London to the Eastern Mediterranean and the Black Sea and thought it a profitable investment to replace his sailing packets with steamers. ${ }^{51}$ Business was going smoothly, given his privileged

$5^{1} \quad$ Odile Wissmer-Kafkalidis, Stefanos Xenos. Portrait d'une Grec romantique et cosmopolite (1821-1894), MA dissertation, University of Bourgogne (Dijon 1998). 
contacts with Greek commercial houses in Britain and the Levant. By 1857 'The Greek and Oriental Steam Navigation Company' was flourishing and, according to its manager, 'yielded splendid profits'. Xenos had also started to import Danubian grain, shipped to Britain in sailing packets. When he sent the Marco Bozzaris, a powerful steamer of 1,00o tons he had just acquired, to Galați to load a cargo of Indian corn, the goods were rapidly 'sold in advance with a profit of £200o'.52

But Xenos' revolutionary idea was to send to the Danube steam river barges of very shallow draught which he purchased in British shipyards. On seeing such a vessel in the shipyard of West Hartlepool,

a project at that moment shot through my brain. I said to myself, If I could send three such steam barges up the Danube into the shallow waters, let us say as far as Calafat and Oltenitza, where the markets are in which the grain is purchased that is brought down to Galatz and Ibraila in carts, I should be able to buy wheat and Indian corn at at least 5 s. or 6s. less per quarter than they can be bought at Galatz or Ibraila. I could tranship this grain on board the large steamers at Sulina for England. ${ }^{53}$

He did it, and soon the Tzamados, the Botassis, the Bobolina, the Zaimi, the Colocotronis, the George Olympius, the Londos and the Rigas-Ferreos, 'each of about 2,00o quarters of grain-carrying capacity and drawing a small draught of water', started to load grain all over the Lower Danube and transhipped it at Sulina on board larger steamers. ${ }^{54}$ In a volume published after he went bankrupt, Xenos proudly exposed his bright commercial ventures: relying on his own steamers (not on chartered vessels), for the maritime stage of the voyage from the Danube to British ports, he shipped his grain through a more reliable, faster and safer means of transportation. River steamers secured his access to cheaper grain upstream the Danube and carried it in faster and better conditions to his seagoing packets.

Xenos' plan was 'comprehensive, and [its] success inevitable'. He lacked, however, the competent and trustworthy human resources to execute his innovative commercial ideas. His first agent in Galați, Henry Stokar, was 'to take the management of the Danube steamers, and buy the grain'. Stokar was an 'honest man', but a bad businessman. Disorganisation reigned in his accounting

52 Stephanos Th. Xenos, Depredations: Or, Overend, Gurney \& Co., and the Greek and Oriental Steam Navigation Company (London 1869), 15.

53 Ibid., 11.

54 Ibid., 38-39. 
books and in the commercial correspondence sent to London. Xenos decided to audit Stokar's affairs and sent two other agents to the Danube, a Greek from Smyrna named Theologos and a Scotsman, Alexander Carnegie, both more versed in commercial ventures than Stokar. Xenos was aware that his own success 'depended entirely on the capacity, the tact, and the good commercial management' of his agents. ${ }^{55}$ But Theologos and Carnegie had plans of their own and used their position to embark upon large business transactions by 'cannibalising' their employer's ideas, steamers and capital. When Xenos could not pay his debts and lost his steamers to his creditors, Theologos and Carnegie took over the entire business network. ${ }^{56}$ To Xenos this was a story about personal dishonesty and commercial breach of trust. To Theologos and Carnegie everything was about hard work and perseverance in a volatile market which required adaptability and versatility. To this narrative, it is about the arrival of river steamers and how they changed the entire commercial environment of the Lower Danube.

Carnegie ordered six similar vessels of between 200 and 300 registered tons to the Austrian shipyards of Linz and Vienna. The Adder, the Bee, the Crane, the Duck, the Eagle and the Ferret started to ply on the Lower Danube in 18641865 , and it took some time to clarify the status of all these vessels. They were 'foreign' ships, and the British consulate in Galați provided them with provisional passes to attest to their identity and protect their interests. ${ }^{57}$ This stood at the beginnings of transnational practices in shipbuilding and shipping along international waterways. Carnegie's vessels' exceptional status had to do with the fact that they were outside the provisions of the British Commercial Merchant Act of 1854, as it was not possible 'to apply the law made for seagoing vessels registered at British ports to vessels which were not registered, and which navigate exclusively the Lower Danube'.58 Other investors copied the same business model and, from the $186 \mathrm{os}$, steamships started to gradually take over Danubian river traffic. It revolutionised the local market and gave Sulina a central role in Danubian trade and shipping.

\footnotetext{
55 Ibid., 39-49.

56 Ibid., 165 .

57 TNA, FO 78/1883, f. 133-137 (George B. Ward to the Earl of Clarendon, Galați, 30 December 1865).

$5^{8}$ Ibid., f. 79-8o (Arthur Raby to John Russell, Galați, 29 May 1865), 102-107 and 139-140 (Ward to Russell, Galați, 14 July 1865).
} 
Despite the Commission's great hydraulic and normative works, lighterage remained a defining feature of the Lower Danubian grain trade throughout the nineteenth and into the early twentieth century. Although the Commission managed to deepen the Sulina bar and the most dangerous passages along the Maritime Danube, it was more convenient for large seagoing vessels coming in ballast to wait for their cargoes in the Sulina roadstead. This decreased insurance costs and saved ships the time lost for navigating up a still tortuous and busy river channel. With the transition from sail to steam, more seagoing steamers of a large capacity stopped at Sulina.

The tariff introduced by the Commission in 1860 contributed to the success of riverain shipping with small draught lighters. ${ }^{59}$ As detailed in Chapter 5 , taxation was based on a double sliding scale, 'varying according to the size of the vessels and the depth of the entrance'. ${ }^{60}$ Small lighters, designed to fit to the Danube's hydrography and the Commission's taxation rules, were exempt from duties, so they prospered along the entire Lower Danube: they loaded grain in upstream riverain ports and transhipped it not only at Brăila, but also at Sulina, directly on board large seagoing ships.

Business was facilitated by Sulina's integration into the Romanian economic system after 1878. Companies of river lighters were extremely active from the 1860 s, and their position became quasi-hegemonic in the 1880 s. ${ }^{61}$ But business flourished, and the fleet of river lighters continued to increase. By the early twentieth century there were about 500 barges (schleps) and 60 tugs carrying grain along the Lower Danube. ${ }^{62}$ The number of schleps recorded at Sulina averaged 1,200 for the period 1891-1895, 1,021 for 1896-1900, 1,483 for 1901-1905, 2,182 in 1906 and 2,092 in 1907.63 This flotilla of rivercraft loaded grain in inland ports and carried it to the Black Sea, where it was transhipped on board large seagoing steamers either in the Sulina harbour or in its roadstead. Brăila was the administrative base of this fleet, as ship-owners and grain traders had their

\footnotetext{
59 Ibid., FO 78/3216, unnumbered files (John Stokes to Russell, Galați, 11 July 1860).

6o John Stokes, Autobiography (s.l. s.a.), 79 .

61 Quoted in Gelina Harlaftis, A History of Greek-Owned Shipping. The Making of an International Tramp Fleet, 1830 to the Present Day (London 1996), 76-79.

62 Gustave Demorgny, La question du Danube: Histoire politique du Bassin du Danube, étude des divers régimes applicables à la navigation du Danube (Paris 1911), 136 .

63 Constantin I. Băicoianu, Le Danube. Aperçu historique, économique et politique (Paris 1917), 118.
} 
offices there, but Sulina was the largest operational centre for the transhipment of cargoes. ${ }^{64}$

The Commission's taxation policy had much to do with its economic situation. According to the 1902 tariff, seagoing ships paid tax of 1.10 francs per register ton at Sulina but avoided the costs of ascending to Galați and Brăila (which incurred additional costs of 0.60 francs per register ton). Fluvial lighters paid no fees to the Commission, and the large investments by private owners in handling equipment made the transhipment of cargoes at Sulina convenient and cheap.

TABLE 7 Share of Sulina in overall shipping on the Maritime Danube, $1861-1915$

\begin{tabular}{llrlrll}
\hline Year & \multicolumn{2}{l}{$\begin{array}{l}\text { A. Ships loaded } \\
\text { at Sulina }\end{array}$} & & \multicolumn{2}{l}{$\begin{array}{l}\text { B. Ships loaded in an } \\
\text { inland port }\end{array}$} & \multicolumn{2}{l}{$\begin{array}{l}\text { Share of Sulina in total } \\
\text { Danubian navigation (\%) }\end{array}$} \\
& Number & Tonnage & Number & Tonnage & Number & Tonnage \\
\hline $1861-1865$ & 1,403 & 478,379 & 12,786 & $1,648,333$ & 9.89 & 22.49 \\
$1866-1870$ & 2,003 & 827,915 & 10,524 & $1,827,441$ & $15 \cdot 99$ & 31.18 \\
$1871-1875$ & 1,385 & 786,492 & 8,371 & $1,831,431$ & 14.20 & 30.04 \\
$1876-1880$ & 991 & 889,788 & 7,351 & $2,198,872$ & 11.88 & 28.81 \\
$1881-1885$ & 1,433 & $1,608,805$ & 5,978 & $2,512,688$ & $19 \cdot 34$ & 39.03 \\
$1886-1890$ & 1,347 & $1,644,457$ & 7,179 & $4,855,490$ & 15.80 & $25 \cdot 30$ \\
$1891-1895$ & 1,312 & $1,728,482$ & 7,079 & $6,278,542$ & 15.64 & 21.59 \\
$1896-1900$ & 1,290 & $1,842,253$ & 5,323 & $5,149,593$ & 19.51 & 26.35 \\
$1901-1905$ & 1,691 & $3,059,484$ & 4,831 & $6,349,789$ & 25.93 & 32.52 \\
$1906-1910$ & 1,712 & $3,408,350$ & 4,141 & $6,429,576$ & 29.25 & 34.65 \\
$1911-1915$ & 1,571 & $3,187,161$ & 2,719 & $4,513,319$ & 36.62 & 41.39 \\
\hline
\end{tabular}

SOURCE: LA COMMISSION EUROPÉENNE DU DANUBE ET SON QEUVRE DE 1856 À 1931 (PARIS 1931), 512 (ANNEXE XXXIII), WITH SHARES RECALCULATED

64 Discussions on the role of the Commission in Sulina's development in Constantin Iordachi, 'Global Networks, Regional Hegemony, and Seaport Modernization at the Lower Danube,' in: Biray Kolluoğlu and Meltem Toksöz (eds.), Cities of the Mediterranean: From the Ottomans to the Present Day (London 2010), 167-169; Dimitrios M. Kontogeorgis, 'Romanian Danubian and Black Sea Ports during the Nineteenth Century: A Quest for Modernization,' in: Heleni Porfyriou and Marichela Sepe (eds.), Waterfronts Revisited: European Ports in a Historic and Global Perspective (New York 2016), 44-58 and Constantin Ardeleanu, 'Romania's Investments in Its Maritime Ports (1878-1914),' in: Ardeleanu and Andreas Lyberatos (eds.), Port Cities of the Western Black Sea Coast and the Danube. Economic and Social Development in the Long Nineteenth Century (Corfu 2016), 102-131. 
With increasing protests from business associations in the inland ports of Brăila and Galați, Romania started to push the Commission to change the tariff. Commissioner Constantin Nanu insisted that it was unfair to exempt large river schleps from shipping dues and proposed an adjustment of the tariff by making it more advantageous for average steamers to call at inland harbours. The new tariff was eventually concluded in May 1908 and was applied from 1 July 1908. The regulation was good for the organisation's budget, but it hardly affected Sulina's prosperity, which remained the preferred grain transhipment station. In fact, Sulina provided better and quicker facilities for the mechanical handling of cargo than inland ports. Already in the early 1880 s several modern elevators were available at the mouth of the Danube. Their number increased to ten in the 18 gos and to twenty-six before the First World War. ${ }^{65}$

Growing business opportunities brought to Sulina a large floating population employed in stevedoring. With hard labour conditions and poor payment, work conflicts and socialist propaganda gradually made their way into the cosmopolitan port. A local Workers' Club was established in 1897, and strikes followed in 1895,1908 and $1913 .{ }^{66}$ As Romania's maritime commissioner, Eugeniu P. Botez paid special attention to this aspect and tried to preserve social order by mediating agreements between stevedores, middlemen and traders. When, in 1910, a shipping company brought 150 stevedores to Sulina to speed up its loading operations, it sparked a conflict with local workers, but this also resulted in the Romanian official's quick and effective intervention. ${ }^{67}$

The Commission was Sulina's most important source of prosperity. From many perspectives, through its role in the administration, economy and social life of the local community, Sulina had become the veritable 'company town' of an IO. ${ }^{68}$ But this complete dependence on its harbour and grain trade operations also brought Sulina's ruin. The Maritime Danube took only a small share of Romania's growing oil exports, which since the late nineteenth century brought new commercial opportunities to the seaport of Constanța. To Botez, the simple explanation was that whereas other port-cities developed alternative economic functions, 'Sulina was only a port, not a city'. ${ }^{69}$ When Black Sea

65 Maria Magdalena Tuluș, 'Aspecte privind evoluția porturilor și căpităniilor portuare dunărene între anii 1878-1916,' Danubius 26 (2008): 107.

66 Gh. I. Ioniță, 'Retrospective revoluționare tulcene (secvențe din cronica unor memorabile lupte trecute), Peuce 4 (1973-1975): 305-316. Other details in Bîrdeanu, 'Greva muncitorilor portuari din Sulina - noiembrie, 1913,' Studii și articole de istorie (1967): 167-179.

67 Mohanu, Jean Bart, 129-130.

68 John Garner (ed.), The Company Town: Architecture and Society in the Early Industrial Age (Oxford 1992).

69 Botez, Europolis, 110. 
shipping decreased during the Balkan Wars and then the Turkish Straits were closed after the Ottoman Empire joined the First World War, Sulina's prosperity was doomed.

\section{From Transnational Brigands to European Bureaucrats}

Demographic analysis is one of the many aspects which shows the huge transformation of Sulina during the long nineteenth century. The town numbered 1,755 inhabitants in 1856 and 2,875 in 1879, when the Romanian authorities conducted a census. Its population grew to about 4,500 people in the late 1890 and by the First World War, there were about 7,00o permanent residents. During the shipping season, the floating population was almost as high, with thousands of stevedores and seafarers coming to Sulina.

The town was targeted by several colonisation programmes, as both the Ottoman and Romanian authorities attempted to change its ethnic structure. Cosmopolitanism, however, remained one of Sulina's defining feature before and after the creation of the Commission. In 1879, the town numbered 2,875 inhabitants, including 1,653 Greeks, 250 Turks, 175 Armenians, 155 Russians, 150 Romanians, 150 Montenegrins, 140 Jews, 85 Brits, 45 Germans, 24 Italians, 15 Bulgarians, 15 Lipovans, 9 French, 6 Albanians and 3 Poles etc. ${ }^{70}$ By the late nineteenth century, its ethnic composition comprised 2,400 Greeks, $45^{0}$ Romanians, 450 Russians, 350 Germans, 230 Jews and 115 Armenians etc. ${ }^{71}$ As approximate as such categories are, with ethnicity and citizenship often deliberately confused, the gradual Romanianisation was already visible in 1912, when Romanians represented 2,891 people in a total population of 7,347, and in 1930, when 3,018 of the 6,399 inhabitants were Romanians. ${ }^{72}$

But more than the quantitative growth, it was the professional structure of the population that changed greatly during this period. Sulina was always regarded as a 'pirate den', whose 'civilisation' by the rule of law was presented as one of the Commission's most important accomplishments. To a Canadian author writing in the early twentieth century, 'Sulina used to be a nest of pirates' or rather, it was full of petty entrepreneurs taking advantage of the existent navigational obstacles that were reduced, but never completely removed, by the Commission. When she lived in Sulina in the mid-1910s, 'the most remarkable citizen' was Don Giovanni, a cunning and enterprising Maltese man of

\footnotetext{
70 Ștefan Sturdza, Expunerea situațiunei plasei Sulina judeciul Tulcea (Tulcea 1880), 32-47.

71 Bondar et alii, Sulina, II, 23.

72 Ibid., 29-30.
} 
about seventy years of age, whose wife and daughter dressed according to the latest Parisian fashions. His greatest source of wealth had been salvaging:

hanging about disabled ships like a vulture until they were obliged to call for his help; taking extraordinary risks in conveying cargoes in leaky tubs to Constantinople; even hauling barges and rafts of logs across the sea with a tiny tug of which he was the captain and the crew - if one can believe the legends. ${ }^{73}$

The bold adventurers of the early period were gradually replaced by whitecollar businessmen and European bureaucrats. Sulina was perhaps unique in terms of the large number of Romanian and international officials based in a town its size. In Europolis, Botez depicts how local hierarchies were easily visible in the seating options available in a fashionable taverna:

Near one of the windows, towards the quay, a large table was reserved for national authorities. It was the so-called table of local chiefs: Mayor, Head of Police, Chief of the Customs House, Chief of Post Office, Harbour Master, Officers, Doctor, Judge. The diplomatic table stood near the other window, to which career consuls and honorary consular agents came. Sometimes, very rarely, an official from the European Commission of the Danube would sit there. Certain prerogatives and privileges, inherited from the capitulatory regime active under the Ottoman Empire, rose in people's eyes the Commission's staff to the highest diplomatic level. Some distance, a discreet reserve, was always tactfully kept between the two worlds that met in the port-city's life. Then there were the tables of captains of steamers, of tugs, of barges, and the table of commercial agents. Stevedores and boatmen would not come into the elite's coffeehouse. ${ }^{74}$

Ten states had consulates in Sulina in 1889 (Austria-Hungary, Belgium, Denmark, Great Britain, Greece, the Netherlands, the Ottoman Empire, Russia, Spain, and Sweden \& Norway), and eight were mentioned in 1902, as the latter two countries had closed their consular offices. ${ }^{75}$ Honorary consuls were often involved in trade and shipping operations, as some form of consular prestige

73 Pantazzi, Roumania, 118-119; also see N. Ionescu-Johnson, Însemnările unui marinar, vol. I (Bucharest 1956).

74 Bart, Europolis, 12-13.

75 Lista corpului consular în România (Bucharest 1889) and Liste de Messieurs les Membres du Corps Consulaire en Roumanie (Bucharest 1902). 
was always useful when doing business in the East. William Wright took over the office of Dutch vice-consul to Sulina in December 1880 from his father, and he remained in office for a long time, though his profession as ship chandler was thought incompatible with his consular attributions. ${ }^{76}$ Similarly, the Belgian vice-consulate was granted to George Inglessi who came from a wellknown commercial and ship-owning family. ${ }^{77}$ Similar cases can be shown for most of the other 'diplomats'.

Most of the Commission's services were based in Sulina, and their chiefs were visible members of the local elite. The Technical Service, led by the engineerin-chief, was the most important one, as the office was held by Sulina's 'father', Sir Charles Augustus Hartley. He was succeeded by two Danish engineers, Charles (Karl) Leopold Kühl and Eugene Magnussen, both of whom spent their entire lives in Sulina. As a courtesy to the territorial power, the Harbour Master's Office was an Ottoman institution until 1878, and Austrian-Hungarian navy captains held the post once the Commission became a fully independent IO. The Navigation Chest and the Commission's Hospital were more cosmopolitan regarding their chiefs, as Belgian, English, French, German, Italian and Romanian subjects directed them from 1856 to 1916 (Chapter 7 ). Such bureaucrats and technocrats had fascinating life stories and used their professional expertise and life experience in service of their adoptive community. For instance, Henry A. Jackson, mentioned in Chapter 4, was an Englishman who settled in Galați in the late 1840s, and intermediated a loan for the Commission, eventually accepting the office of chief of the Navigation Chest. While in Sulina, he encouraged local cultural endeavours and pursued his scholarly interests, which resulted in the publication of a volume on Romanian history and literature. ${ }^{78}$ Fran Vilfan (Franz Wilfan in German spelling) was a naval officer of Slovenian origin, who served as Sulina's harbour master from 1903 until the end of the First World War. Vilfan graduated in Trieste and attended the Naval Academy of Fiume before joining the Austrian-Hungarian navy. His warship was sent to the Far East as part of the joint naval expedition despatched to China after the Boxer Rebellion. In his post-Sulina career, Vilfan equally benefited from his Danubian expertise. He went to the Paris Peace Congress in 1919 as a naval expert in the Yugoslav delegation and was later a member of the International Commission of the Danube, the organisation that 'copied'

76 Nationaal Archief, Ministerie van Buitenlandse Zaken, De Nederlandse Consulaire Vertegenvoordiging in Roemenië, 1860-1954, Inv. no. 389.

77 Lista corpului consular, v.

78 Henry A. Jackson, A Series of Lectures upon Roumanian History and Literature (London 1884). 
the Commission to regulate navigation on the Fluvial Danube in the interwar years. ${ }^{79}$

Chief pilots were as important, and most of them were of Greek origin. According to data from 1901, 73 out of the 88 pilots licensed by the Commission were Greeks. Nicolas Barbatis joined the Commission in $185^{8}$ as deputy chief and was chief pilot from 1860 to 1900 . He was followed by another legendary character, Spiru Baracioglu. A Greek born in Trabzon, Baracioglu married a Muslim woman and converted to Islam. He was an experienced seafarer and shipmaster when he joined the Commission in 1879, and in the interwar years Baracioglu was a pioneer of Romanian yachting, when this sport was little known in the Black Sea area. ${ }^{80}$

The high salaries paid by the Commission were the main incentive to convince such people to settle in Sulina. Whereas the Romanian mayor of Sulina would earn 3,60o lei (francs) a year and a municipal copyist earned 1,20o lei, the resident engineer got 22,00o lei, and the harbour master and the director of the Navigation Chest 13,00o lei. The minimum wage for the Commission's lower staff was 1,200 lei. ${ }^{81}$

Another significant change, which impacted the development of local social and cultural life, was the arrival of women. In 1880 the population included 1,470 men, 545 women and 860 children, but by 1896 the number of women and children had almost doubled: 1,500 men, 957 women and 2,043 children. ${ }^{82}$ The settlement of women is perhaps a good indicator of the increased security and stability of Sulina, but also of the Commission's good matrimonial relations. An illustrative example is that of the Bigg-Withers. While in Britain in 1863, commissioner John Stokes met some relatives, who were anxious about the future of their grandson, Harris Bigg-Wither, 'a nice boy of about 16'. Stokes took him out to Sulina, where he worked for the Navigation Chest. He lived there for some time, and eventually married Constance, one of Stokes' daughters. ${ }^{83}$ Harris Bigg-Wither was accompanied to Sulina by his sister Alice, where she met Danish engineer Kühl, Hartley's assistant and the Commission's resident engineer, whom she would later marry. The couple lived on the Lower Danube

79 Österreichische Biographische Lexikon 1815-1950, vol. 15 (Vienna 2017), 279-280 (online at http://www.biographien.ac.at/oebl/oebl_V/Vilfan_Fran_1874_1931.xml) (visited on 19 September 2017).

8o NAR, Galați Branch, Fond Comisia Europeană a Dunării, Secretariatul General (Dosare Personale), File 156.

81 Budgetul de veniturile și cheltuielile comunei Sulina pe anul 1891-1892 (Sulina s.a.) and PECD, Protocol 471, 13 May 1890.

82 Sturdza, Expunerea, 32-47 and Bondar et alii, Sulina, II, 23.

83 Stokes, Autobiography, 84. 
until Kühl's retirement in 1907 and Alice, 'a charming Englishwoman, refined and sympathetic $[\ldots]$ brought to her little Sulina cottage [...] all the comfort and homeliness of the British.' ${ }^{84}$

In 1905, Giulio Martone became chief of the Commission's hospital, and his family moved from Naples to live with him in Sulina. Georgio Martone was five months old when he arrived at the Danube, where he spent the next ten years of his life. He returned to the Danube in 1924 and worked for the organisation for twenty years. In his memoirs, Martone depicted his happy childhood in that 'Babel of human races, languages and colours'. His mother, educated in Florence and fluent in both English and French, missed a cultural environment and invested in establishing, with support from Rome, an Italian cultural centre called 'Dante Alighieri'. In early twentieth-century Sulina, one could study Italian, learn different handicrafts or borrow a book. ${ }^{85}$

Scholars have studied the relationship between gentrification and security in different historical, geographical and social contexts. At Sulina, excluding the foreign consuls and the Commission's employees, the population consisted 'almost entirely of ship agents, ship chandlers, stevedores, gangs of ships labourers, and tavern-keepers'. ${ }^{86}$ After 1856 they did not face chronic anarchy, and their lives were no longer endangered by high levels of criminality, but there were other threats lurking in the neighbouring marshlands.

Urban Transformations - Geological Cosmopolitanism and Modern Public Services

Sulina's development in the second half of the nineteenth century was branded as an example of what European cooperation could achieve. In relation to the town's urban transformation, two complementary processes will be briefly analysed below: the growth of Sulina by land reclamation, and providing the town with regular urban planning and state-of-the-art public services.

84 Hartley, A Biography, 586-587.

85 Ion Calafeteanu, 'Sulina în amintirile unui italian,' in: Aurel-Daniel Stănică and Cristian Leonard Micu (eds.), Istro-Pontica 2. Studii și comunicări de istorie a Dobrogei. Actele Sesiunii Naționale de Comunicări Științifice "Istro-Pontica. Tulcea - 505 ani de la prima atestare documentară", Tulcea, 28-30 septembrie 2011 (Brăila 2014), 67-70; Alina Dorojan, 'Italienii din spațiul românesc în secolele XIX și XX. Istorie, demografie, societate,' in: Bokor Zsuzsa (ed.), În căutarea tărâmului promis: Italienii din România (Cluj-Napoca 2017), 135 .

86 British Parliamentary Papers. Reports from Her Majesty's Consuls on the Manufactures, Commerce, \&c. of Their Consular Districts (London 1884), 742 (Report by Acting ViceConsul Macdonald on the Trade and Navigation of the Danube, 1883). 
The Commission was actively involved in both and, to paraphrase a recent volume on the Suez Canal, from this perspective Sulina was a symbol of international rule which secured the transformation of a marshland by means of modern technology. 87

Hubert Lyautey (1854-1934), the French army marshal and colonial administrator who earned global fame as French 'empire builder' in Indochina, Madagascar and especially Morocco, visited Sulina in May 1893, where he met Sir Charles. Both the distinguished engineer and his hydraulic masterpiece left a lasting impression on the Frenchman. ${ }^{88}$ His reference to Sulina, quoted in the motto for this chapter, stands as a tribute to a sort of geological cosmopolitanism which enabled the town to emerge from the neighbouring marshlands. This remains to this day one of Sulina's dearest labels, as a global geological platform capable of making all its motley crew of inhabitants feel at home. ${ }^{89}$

Sulina developed unevenly on both banks of the Danube. In Russian times, the left shore was used to accommodate the quarantine station and the military quarters, and the right side was used for the civilian settlement. When the town started to develop after 1856 , this distinction was maintained, as the right bank was better suited for land reclamation from the neighbouring marshland. Sulina developed by stretching the band of dry land along the river and widening it to allow the creation of streets parallel to the riverbank. According to available plans, in the late 1850 s there were only two parallel streets, stretching for about $1.5 \mathrm{~km}$ along the right shore. In 1896 there were three parallel streets, and by 1900 a fourth one marked the town's swamp limit. Sulina continued to expand during the twentieth century, and now has six parallel streets along the main, right shore settlement. ${ }^{90}$

The Commission played the central role in Sulina's urban revolution. Sir Charles had a hut in Sulina and while living there in the early 186os, witnessed its many problems and helped to solve them. Sometimes his immediate intervention was rendered necessary by natural factors. A severe Black Sea storm in 1864 affected not only the Commission's hydraulic works, but also private houses in Sulina. The town was often flooded, as occurred in 1865 when it risked being completely submerged. Hartley decided to intervene and built up

\footnotetext{
87 Huber, Channelling Mobilities, 4.

88 Michael P.M. Finch, 'Imperial Connections: Frederick Lugard, Charles Hartley, and Hubert Lyautey's English Influences,' The Journal of Imperial and Commonwealth History 46.6 (2018): 1044-1066.

89 Hubert Lyautey, Lettres de jeunesse : Italie - 1883; Danube - Grèce - Italie - 1893 (Paris 1931), ${ }^{148-15^{2}}$ in the translation from Hartley, A Biography, 586.

9o Bondar et alii, Sulina, II, 221-231.
} 
the sides of the fissure with stones. ${ }^{91}$ Under his supervision, the town was reinforced by dykes on both banks, and in various portions the settlement was extended against the marshland. The Commission further cleared up marshy areas, changed the drainage channel of the muddy waters surrounding Sulina and built bridges to regulate circulation across these rivulets. At the request of the municipality, it used its dredgers to bring alluvium from the river and raise the floodable parts of the town. A solid tarmacked roadway was progressively built along the right shore all the way to mile 5 , and a pedestrian walkway was demarcated along the quay in Sulina's busiest areas. ${ }^{92}$

Such works highlight the Commission's unique qualities as an IO through its intimate involvement in the transformation of its host city. ${ }^{93}$ Its staff was also involved in urban planning. By 1866 , an order was issued by the Ottoman authorities to systematise downtown Sulina, in an area 'abutting on the river' and 'forming the market-place', where 'Greeks and other Christians' had their shops. ${ }^{94}$ On the new city plans the Commission saved the central area for itself. On the left, 'industrial' bank, the Commission built a shipyard, workshops, storehouses, and offices for its technical and financial services, as well as several dwelling houses for its staff. Along the right, civilian shore, the Commission had its administrative headquarters, offices for the Technical Service, two hospitals, a lighthouse, and several more dwelling houses. In this more regular Sulina, the right bank was systematised on several layers, identified by activities and typologies of buildings and a transversal hierarchy. Streets parallel to the Danube were numbered on the American grid model, with the riverside being the main street. Street no. 1 hosted the administrative and economic quarter, with offices for shipping agencies, commercial houses and consular agencies. The residential quarters of different communities stretched along the other streets. ${ }^{95}$

The Commission saved the best spots for itself, as part of an 'international enclosure'. Its most visible urban brand was the palace it completed in 1868 , a charming neo-classical building. A contemporary account colourfully describes its 'columns, balconies', and the interior designed 'in the most sumptuous Victorian style'. It had a 'red room, a green room', according to 'the colour of the wallpaper and curtains. The President's office fascinated me. It was taped

\footnotetext{
91 Hartley, A Biography, 204-205.

$92 \quad$ La Commission, 344-346.

93 Bondar et alii, Sulina, I, 64.

94 St Clair and Brophy, A Residence, 272.

95 Dorothée Rietsch, 'Sulina, ville dans le delta du Danube, Roumanie,' ICOMOS 17th General Assembly, 2011-11-27 / 2011-12-02, Paris, France (Paris 2012): 207-220 (online at http://open archive.icomos.org/1153/1/I-3-Article8_Rietsch.pdf) (visited on 15 November 2018).
} 
with rotten-cherry velvet. The furniture was mahogany, with leather caught in brass spikes, and a pedestal hosted a huge globe with Latin characters. ${ }^{96}$

With such a variety of administrative and residential quarters, Sulina was a town of contrasts, rendered even more evident by its rather small size. To a British traveller who visited the town in the mid-1870s, Sulina was both a triumph of urban transformation and an image of desolation:

Sulina itself, with its two splendid piers, lighthouses, and harbour, is the creation of the Danube Commission, mutato nomine of Sir Charles Hartley. It is a desperately ugly little place, and appallingly dull. [...] Sulina impressed me as being at the end of the world - a little further Eastward, and surely we should tumble over the edge into space. It had a forlorn, fragmentary, chaotic aspect. [...] In a word, it was one of the last places on earth in which one would choose to live. ${ }^{97}$

Despite Beatty-Kingston's disheartening conclusion, Sulina continued to change under the influence of its cosmopolitan inhabitants. The Commission contributed by connecting the town to the world and by introducing modern public services. As early as 1857 , a telegraph line was established between Sulina and Galați. This was one of the earliest lines in the Ottoman Empire. Meant to secure a fast connection and coordination between the Commission's main headquarters in Galați and its operational centre at Sulina, the telegraph favoured the economic development of both ports. By the mid-186os, Hartley built a timber quay on the right riverbank, so regular steamboats could land at Sulina. With institutional money, substantial quays were constructed on both shores, encouraging postal vessels and larger steamers to call at the local harbour. ${ }^{98}$

Finally, the Commission contributed to Sulina's public lighting and drinking water supply. From 1903, oil lamps were used along the quay, and electric light was introduced in 1910. With a high subsidy paid by the Commission to the contractor, electricity expanded throughout the town and into private houses. The lack of good drinking water sources was a serious problem for local inhabitants and seafarers calling at Sulina, so construction of a modern water plant began in the 189os, according to the recommendations of the International Health Conferences of Dresden (1893) and Venice (1897). ${ }^{99}$

96 Gh. Jurgea-Negrilești, Troica amintirilor: Sub patru regi (Bucharest 2007), 166.

97 W. Beatty-Kingston, $A$ Wanderer's Notes, vol. II (London 1888), 36-38.

$98 \quad$ La Commission, 346.

99 Ibid., 346-347. 

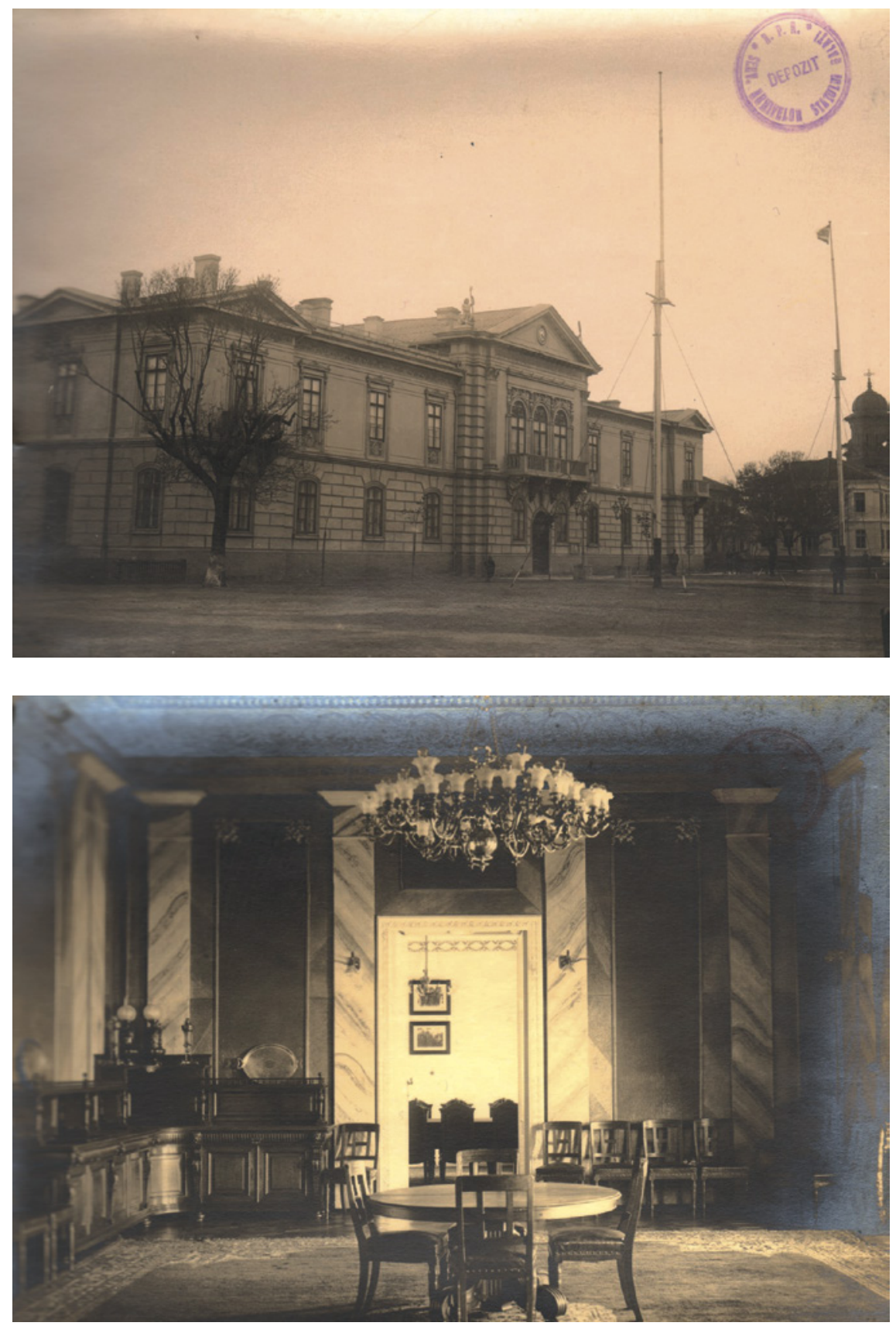

FIGURES 19-20 The Commission's palace in Sulina (1930) SOURCE: THE NATIONAL ARCHIVES OF ROMANIA, GALAȚI BRANCH 
To Lyautey, Hartley's transformation of the Lower Danube was an example for his own civilising mission as a colonial administrator. The engineer's diligence was equally visible in his river works that had 'tamed' the mighty Danube, and in his transformative contribution to turning Sulina from a collection of 'miserable huts' into 'a town and a port'.100 But the praise for the engineer's genius was equally an acknowledgement of his great institutional supporter, the Commission, whose responsibility was to provide good working and living conditions for its employees involved in regulating the Danube.

\section{Cholera, Malaria, Typhoid Fever - on the Danube Delta's Silent Threats}

On 30 July 1865, an Ottoman transport steamer arrived from Istanbul in the roadstead of Sulina. Two men on board had died from cholera during the voyage. The crew disembarked at once, and as several people suffered from choleric symptoms the entire crew was isolated. Twelve new cases were recorded, and five people died during the next two days. On 2 August, Dr Jellinek, the Commission's chief physician, noticed a person sick with cholera among a group of labourers who had come from Galați. Another case, an employee in the service of the deputy governor, was discovered the same day. The epidemics would last for most of August 1865 and purged the entire settlement. Among its 3,000 inhabitants, half fled, but 300 of the $35^{\circ}$ people who contracted the disease allegedly died. ${ }^{101}$ The town was devastated, and further action needed to be taken to combat the spread of the disease.

As a communication hub along major Black Sea and Danubian routeways, Sulina was often confronted with such terrible, to borrow from Jürgen Osterhammel, 'mobile perils' ${ }^{102}$ In Russian times, Sulina was chosen to host a quarantine station, but its sanitary regulations were considered 'burdensome in the extreme' to international trade and shipping. Article 15 of the 1856 Paris

100 Lyautey, Lettres du Tonkin et de Madagascar (1894-1899), vol. 1 (Paris 1920), 291; references also in Hartley, A Biography, 586-589.

101 Jules Girette, La civilisation et le choléra (Paris 1867), 277-278 and Reports from Commissioners, Inspectors, and Others, vol. 40 (London 1875), 53. See also Hartley, A Biography, 207-208.

102 Jürgen Osterhammel, The Transformation of the World. A Global History of the Nineteenth Century (Princeton 2015), 185. Sulina can be compared with the situation of the Suez Canal, as described by Huber, Channelling Mobilities, 241-271. 
Treaty stated that more balanced quarantine regulations had to be drafted, which should favour, as much as possible, 'the circulation of ships.'103

When cholera struck in 1865, health policies along the Maritime Danube were implemented by a Sanitary Service of the Mouths of the Danube, subordinated to the Istanbul-based Superior Health Council. This international institution was established in 1839 and aimed to regulate shipping in Ottoman ports. ${ }^{104}$ At the Danube, it advised the imposition of more rigorous sanitary measures, which hindered both commercial navigation and the movements of river police during epidemic outbursts such as that of 1865 .

The Commission was in a difficult position, forced to choose between more sanitary safety and its own survival, as its budget, technical works and institutional success depended on free circulation of ships along the Maritime Danube. The 1865 Public Act regulated quarantine procedures as a compromise between 'the guarantees of [sanitary] security and the needs of the maritime trade'. It also detailed health procedures and the possibility of instituting additional quarantine establishments in case of new epidemics. ${ }^{105}$

When Romania acquired the Danube Delta in 1878 , sanitary regulations had to be updated. According to an agreement concluded in 1881, sanitary norms applicable at the Lower Danube (including sanitary tariffs) were drafted, together with the Commission, by an International Health Council based in Bucharest, which in fact was never established. As further proof of honest cooperation, the Romanian Health Office in Sulina was led by the same physician that directed the Commission's hospitals, who made sure that health policies were accessible to both Romania and the Commission. ${ }^{106}$

Sulina was exposed to many other sanitary hazards. Situated in a marshland with poor drinking water supplies, infected by miasmas, and tormented by mosquitoes, the town was often the victim of malaria and typhoid fever. Immediately after its establishment, the Commission set up a hospital in Sulina, and another one at Tulcea, although the latter closed in 1865. The first chief physician was a certain Engelhardt, probably a relative of the French commissioner, soon followed by Jellinek, a graduate of the Viennese medical school. That this was a very good position is shown by the number of doctors

103 Congrès de Paris, 11.

104 Birsen Bulmus, Plague, Quarantines and Geopolitics in the Ottoman Empire (Edinburgh 2005); Nermin Ersoy, Yuksel Gungor, and Aslihan Akpinar, 'International Sanitary Conferences from the Ottoman Perspective (1851-1938), Hygiea Internationalis 10.1 (2011): $53^{-79}$.

105 London Gazette, No. 23105, 24 April 1866.

106 La Commission, 353-356. 


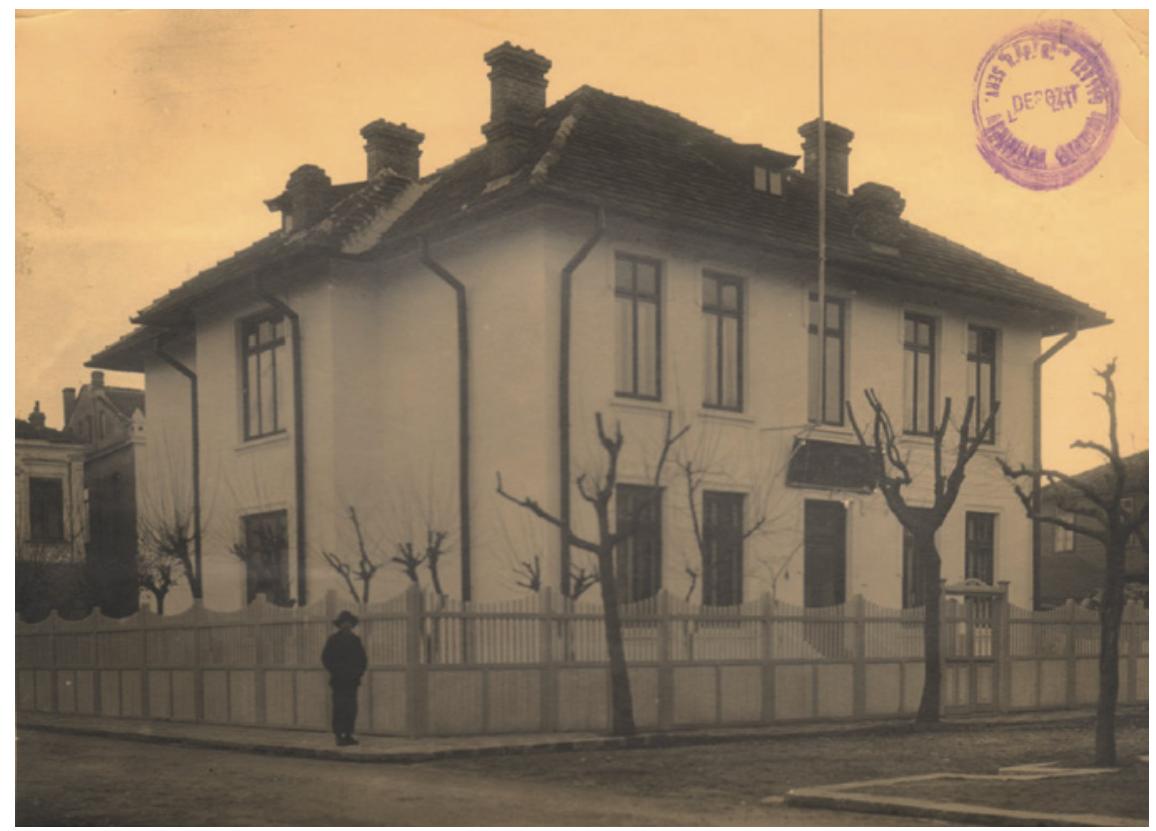

FIGURE 21 The hospital of Sulina (1930)

SOURCE: THE NATIONAL ARCHIVES OF ROMANIA, GALAȚI BRANCH

who sought to replace Jellinek, when he retired in 1870 . Nineteen candidates applied for the position, and they were selected based on their 'technical aptitudes', 'moral qualities and character', and 'knowledge of foreign languages in use at the Lower Danube'. Five applicants were preselected, and the winner was Frenchman Valentin Vignard, a physician formerly in the service of the Messageries Impériales shipping company. Vignard would live in Sulina for the next seventeen years. ${ }^{107}$ Medical journals of the time published several of his scientific contributions, including an article entitled 'De la nécessité dans l'état moderne de la création d'un Ministère de médecine publique' (1880). After a brief interlude, a new chief physician, Romanian Petrescu Hagi-Stoica would stay in office for the next three decades, between 1890 and 1921.

In its initial stage, the Sulina hospital was hosted in a rented house and exclusively treated the Commission's staff. In 186o, European commissioners decided to open the hospital to ship-owners and Ottoman employees of the local Harbour Master's Office. In March 1861, a new regulation established that half

107 CADN, CED/B/19 (Correspondence to Commissioner Adolphe d'Avril), f. 304-312 (Proceedings of the Executive Committee, 4 August 1870). 
of the available beds were to be reserved for the treatment of international seafarers, and the other half for the Commission's lower staff. All patients admitted into the hospital had to pay a small daily fee, and the establishment was also open to local inhabitants. In 1863 , the Commission decided to increase its tariff and use the extra income for opening the hospital to seamen of all nations. A proper building to serve as the naval hospital was completed in 1869 , and it included an isolated pavilion for cholera cases. A new regulation was drafted, implementing free treatment for the Commission's pilots, lower staff and workers. Medical staff included a chief physician, assisted by a physician and two nurses. It functioned in this structure until 1893, when a separate hospital for epidemic diseases was built, in line with developments in medical science. ${ }^{108}$

A good indicator of the efficiency of Sulina's public services can be seen in its malaria cases. Of the patients admitted into the hospital in 1868-1870, 31.2 per cent suffered from malaria, a proportion that fell to 25.33 per cent for 1871-1880, followed by 14.77 per cent, 7.94 per cent, 4.34 per cent and 3.13 per cent for the next four decades. ${ }^{109}$ The Canadian traveller mentioned above referred to this when she visited the 'little gem of a hospital' on the Commission's property: "Typhoid and dysentery used to take an annual toll of many lives until the fine new waterworks were installed and the water carefully filtered and oxygenated. Now these diseases are almost unknown. Malaria only gets the newcomers - the Sulinites seem immune.'110

But despite her optimistic conclusion, there was something utterly frail and unhealthy at Sulina. The introduction of public services and imposition of modern hygiene regulations improved the inhabitants' quality of life, but the neighbouring marshland left its imprint on everyone and everything, in human bones and house structures. Everything was damp, and houses were slowly sinking. Stone could hardly be used as a building material, as the dampness would immediately attack it. With ground water lying less than one metre deep, houses were as frail as the health of Sulina's inhabitants. Underneath Sulina's modern appearance lay an inconvenient structural weakness. ${ }^{111}$

\footnotetext{
108 La Commission, 334-337.

109 Ibid., 345.

110 Pantazzi, Roumania, 125.

111 F. Brunea-Fox, 'Farmecul Dunării: Sulina,' Realitatea ilustrată 83-84 (1934): 16-17.
} 
TABLE 8 Movement of patients in Sulina's Central Hospital, 1861-1920

\begin{tabular}{|c|c|c|c|c|c|c|c|}
\hline \multirow[t]{2}{*}{ Period } & \multicolumn{3}{|c|}{$\begin{array}{l}\text { Number of hospitalised } \\
\text { patients }\end{array}$} & \multirow[t]{2}{*}{$\begin{array}{l}\text { Days of } \\
\text { hospitalisation }\end{array}$} & \multicolumn{3}{|c|}{ Categories of patients } \\
\hline & Medical & Surgery & Total & & Seamen & $\begin{array}{l}\text { Pilots and } \\
\text { Commission } \\
\text { employees }\end{array}$ & Sulinites \\
\hline $1861-1870$ & 1,860 & - & 1,860 & $18,85^{\circ}$ & 1,273 & 587 & - \\
\hline $1871-1880$ & 2,320 & - & 2,320 & 26,420 & 1,423 & 524 & 373 \\
\hline $1881-1890$ & 2,689 & - & 2,689 & 35,605 & 990 & 787 & 912 \\
\hline $1891-1900$ & 4,640 & - & 4,640 & 43,920 & 1,133 & 1,373 & 2,134 \\
\hline $1901-1910$ & 3,080 & $2,25^{8}$ & 5,338 & $5^{8,987}$ & 1,318 & 1,378 & 2,642 \\
\hline $1911-1920$ & 3,217 & 2,874 & 6,091 & 71,896 & 2,104 & 1,812 & 2,175 \\
\hline Total & 17,806 & 5,132 & 22,938 & 255,678 & 8,241 & 6,461 & 8,236 \\
\hline
\end{tabular}

SOURCE: LA COMMISSION, 503 (ANNEXE XXIV)

11 Cosmopolitan Headstones and Their Stories of Insecurity

William Simpson was one of those who would fit well into this image of frailty. He was one of Hartley's close associates in the Technical Service, and upon his death, probably from malaria, a stone was erected in the local graveyard: 'Sacred to the memory of William Simpson who died at Sulina on the 28thJuly 1870 aged 46 years. This stone was erected by the European Commission of the Danube by whom Mr Simpson was employed for thirteen years as foreman of the works.' ${ }^{12}$ The monument was a marker of social prestige for the deceased, and the cemetery where it was placed is symbolic of the organisation's interest in improving the life, and equally the death, of its employees.

The town had a small, wooden Eastern Orthodox church, spared by the British troops when they ravaged Russian Sulina in 1854. With the arrival of the Commission's employees, religious services became much more essential to local inhabitants. In 1863 , the Commission decided to support a request from its Catholic employees and sponsored the establishment of a Roman Catholic house of God. In the following years, commissioners contributed

112 Petre Covacef, Cimitirul viu de la Sulina (Constanța 2003), 15-17; Nick Thorpe, The Danube: A Journey Upriver from the Black Sea to the Black Forest ([New Haven] 2014), 17-18. 
to the construction of a new Greek Orthodox church, a place of worship for old rite believers, an Anglican church, and a mosque. From 1868 onwards, the Commission paid, when its budget allowed, an annual subsidy for the support of all faiths. ${ }^{113}$ This marked a new understanding of the Commission's communal mission in relation to its own employees and the larger human environment in which they lived and worked. Being such a cosmopolitan organ, it was necessarily a very liberal one, making no distinction between race, ethnicity or religion.

Churches are religious institutions, but serve other communal needs of believers, too. The Anglican church, built with financial support from the Commission, the local English community and several benefactors throughout Europe, was consecrated in 1871, when it was visited by Bishop Harris of Gibraltar, who was touring the Anglican parishes of the Eastern Mediterranean and Black Sea area. An excellent schoolroom was built for the use of British children, chiefly through the exertions of Sir Charles. ${ }^{114}$ In 1883 a British Seaman's Institute was opened in the courtyard of the Anglican church, aiming to assist the large number of British seafarers calling at the Maritime Danube and prevent them from losing their spirit and money in the too numerous local tavernas. ${ }^{115}$

Given the shortage of land, burying the dead was problematic in Sulina, and the Commission got involved in solving this issue. In 1864 the organisation established a Christian graveyard on an estate granted by the municipality, and in 1871 extended it with an Islamic section. In this multi-ethnic and multireligious cemetery, each of the six main religious groups (Anglican, Catholic, Eastern Orthodox, Jewish, old rite Lipovan and Muslim) had its own section. ${ }^{116}$ The graveyard stands to this day as proof of Sulina's tumultuous history, and its various headstones are an excellent source of documenting various instances of human insecurity. In the Anglican section, eleven Britons are buried, all young people (with an average age of less than 30) who died at Sulina. Most of them drowned or, in the case of a certain Peter McGregor, 'died from the effects of climate'. The Commission reserved its own section in the graveyard, and a headstone was erected 'in memory of William Webster, chief officer on board the S.S. Adalia, who nobly sacrificed his own life by endeavouring to save Margaret Anna Princle from drowning at Soulina on the 21 of May 1868, aged

\footnotetext{
113 La Commission, 342-344.

114 'Notes of a Visitation by the Bishop of Gibraltar,' Colonial Church Chronicle (1869): 177-179; Hartley, A Biography, 279-280.

115 Pantazzi, Roumania, 114.

116 La Commission, 342-343.
} 
25 years'. Katharina Smith, aged 31, 'the beloved wife of William Smith' died of cholera in June 1866, followed by her baby daughter Emily Rose Katharina in August 1866, and the grieving husband and father, aged 37, in December 1868. ${ }^{117}$

Sometimes, when epidemics were raging, there was hardly any time to bury the dead. Cholera reappeared in Sulina on 3 August 1893. Four days later, 27 cases had been recorded, and 39 on 9 August. Fear spread as quickly, and about 2,00o people fled the town. In its harbour, the British steamer the Munificent had seven cases of cholera in its crew, one so violent that the sick seaman was thrown into the sea. Of the 641 patients admitted into the Commission's hospital, 88 had cholera. Forty-one of them died, along with twelve from typhoid fever, six from tuberculosis, five from 'psychological misery', and four from pneumonia. A further 138 people died of cholera in the local lazaretto or in their homes. ${ }^{118}$ Some of these victims lie in the cosmopolitan graveyard, the stone-hewn symbol of Sulina's grandeur and decay, sometimes washed out by a violent storm in the neighbouring sea.

Security is a good analytical framework to look at Sulina's history between 1856 and 1914. A security regime was established in the Danube Delta in the aftermath of the 1856 Paris Peace Treaty, as Sulina was the transportation hub where unscrupulous entrepreneurs capitalised on the area's numerous natural and artificial obstacles. The arrival of the Commission transformed the professional structure of the town, and this cosmopolitan bureaucracy invested knowledge and money in reshaping the urban environment to fit a more 'civilised' model. Modern institutions and public services were part and parcel of the international town. Contemporaries insisted on Sulina's colonial character. From its urban aspect to the privileges of its inhabitants, it was a collective colonial experiment, in which international cooperation served as the building block of communal life.

Seven decades after the Commission's dissolution through the 1948 Belgrade Convention, Sulina faces serious challenges as the EU's most easterly point. With 3,661 inhabitants at the 2011 census (among whom 82 per cent are Romanians and 10 per cent Lipovans), it is far from its former ethnic diversity. In communist times Nicolae Ceaușescu promised to build a road between

117 Covacef, Cimitirul, 12-24.

118 Marin Ionescu-Dobrogianu, Dobrogea în pragulveacului al XX-lea. Geografia matematică, fisică, politică, economică și militară (Bucharest 1904), 300. 
Tulcea and Sulina, but the project was eventually abandoned due to its huge financial and environmental costs. A steamboat runs daily from the district capital of Tulcea, and in about four hours tourists are taken to a natural paradise, a living ecosystem with wild horses, pelicans, sturgeon, water lilies and a fine beach. ${ }^{119}$ But local people complain they are the least protected species in this area listed as a UNESCO World Heritage Site. And, in their insecurity, they look back to the European beginnings of Sulina, in expectation of future support from the EU, in so many ways one of the Commission's heirs. Sir Charles' stone piers still stand to regulate the Danube's flow at the junction of river and sea, the Commission's palace continues to quarter the local fluvial administration, and the old lighthouse welcomes tourists with an exhibition featuring Sulina's 'European' golden times. Europe is wherever you look - back and ahead. But, for now, few benefits are visible for the Sulinites who feel trapped in a temporal and geographical bubble with no escape. As in Botez's Europolis, to Claudio Magris Sulina 'is a symphony of the End, in which the town that sets itself up as a miniature capital of Europe turns into a slum and an abandoned roadstead.'120

\footnotetext{
119 Thede Kahl, Natur und Mensch im Donaudelta (Berlin 2018).

120 Claudio Magris, Danube: A Sentimental Journey from the Source to the Black Sea, translated by Patrick Creagh (London 1997), 398.
} 